\title{
Monthly variation of micro- and macro-element composition in smooth scallop, Flexopecten glaber (Linnaeus, 1758), from the Çardak Lagoon (Çanakkale Strait, Turkey)
}

\author{
Çardak Lagünü'ndeki (Çanakkale Boğazı, Türkiye) deniz tarağının \\ Flexopecten glaber (Linnaeus, 1758), mikro ve makro element \\ kompozisyonundaki aylık değişimler
}

\author{
Pervin Vural $^{1 *}$ - Sefa Acarlı² \\ ${ }^{1}$ Çanakkale Onsekiz Mart University, Bayramiç Vocational School, Department of Aquaculture, Çanakkale, Turkey \\ ${ }^{2}$ Çanakkale Onsekiz Mart University, Faculty of Marine Sciences and Technology, Çanakkale,Turkey
}

Abstract: The present study investigated the total elemental composition ( $\mathrm{Fe}, \mathrm{Cu}, \mathrm{Mn}, \mathrm{Zn}, \mathrm{Al}, \mathrm{S}, \mathrm{B}, \mathrm{Na}, \mathrm{Mg}, \mathrm{K}, \mathrm{Ca}, \mathrm{P}, \mathrm{S}$ ) in smooth scallop (Flexopecten glaber) meat collected monthly in the Çardak Lagoon (Turkey) in 2017- 2018. Considering the distribution of elements in terms of quantity during the year, the elements were sorted as $\mathrm{S}>\mathrm{Na}>\mathrm{K}>\mathrm{P}>\mathrm{Mg}>\mathrm{Ca}>\mathrm{Fe}>\mathrm{Zn}>\mathrm{Mn}>\mathrm{Al}>\mathrm{B}>\mathrm{Cu}>\mathrm{Se}$ and the heavy metals were below the detection limit. Although the elements were at their highest values during autumn and summer, they were at their lowest values during spring and winter. The differences between the months in terms of $\mathrm{Fe}, \mathrm{Mn}, \mathrm{Mg}$, and $\mathrm{Ca}$ elements were found to be statistically significant $(\mathrm{p}<0.05)$. It was determined that the element composition of smooth scallop meat was suitable for consumption in terms of the area where it is collected and is beneficial for health when consumed in the amounts recommended by FAO/WHO, and CODEX. The Hazard Quotient (THQ) and the Hazard Index (HI), which was conducted to evaluate the health risks of consuming smooth scallop, were found below 1 all months. For this reason, smoth scallop consumption in this region does not have any negative effects on human health.

Keywords: Flexopecten glaber, smooth scallop, element, Çardak Lagoon, Çanakkale Strait

Öz: Bu çalışmada Çardak Lagünü'nden (Türkiye) 2017- 2018 tarihleri arasında bir yıl boyunca aylık olarak toplanan smooth scallop (Flexopecten glaber) etinin toplam element kompozisyonu ( $\mathrm{Fe}, \mathrm{Cu}, \mathrm{Mn}, \mathrm{Zn}, \mathrm{Al}, \mathrm{Se}, \mathrm{B}, \mathrm{Na}, \mathrm{Mg}, \mathrm{K}, \mathrm{Ca}, \mathrm{P}, \mathrm{S})$ belirlenmișţir. Elementlerin miktar açısından yll içindeki dağılımına bakıldığında $\mathrm{S}>\mathrm{Na}>\mathrm{K}>\mathrm{P}>\mathrm{Mg}>\mathrm{Ca}>\mathrm{Fe}>\mathrm{Zn}>\mathrm{Mn}>\mathrm{Al}>\mathrm{B}>\mathrm{Cu}>\mathrm{Se}$ sıralamasında olduğu, ağır metallerin ise dedeksiyon limitinin altında olduğu gözlenmiştir. Elementler sonbahar ve yaz döneminde en yüksek değerde bulunmasına karşın, ilkbahar ve kış döneminde en düşük değerde gözlenmiştir. $\mathrm{Fe}, \mathrm{Mn}, \mathrm{Mg}$ ve $\mathrm{Ca}$ elementlerinde aylar arasındaki farklar istatistiksel olarak önemli bulunmuştur $(p<0.05)$. Toplandığı bölge bakımından deniz tarağı etinin element kompozisyonunun tüketim için uygun olduğu ve FAO/WHO, CODEX tarafından tavsiye edilen miktarlarda tüketildiğinde sağlığa yararlı olduğu tespit edilmiştir. Deniz tarağı tüketmenin sağık açısından risklerini değerlendirmek amacıyla yapılan Hedef Tehlike Katsayısı (THQ) ve Tehlike Indeksi (HI) tüm aylarda 1'in altında bulunmuştur. Bu nedenle bu bölgedeki deniz tarağı tüketiminin insan sağlığına olumsuz etkisi bulunmamaktadır.

Anahtar kelimeler: Flexopecten glaber, deniz tarağı, element, Çardak Lagünü, Çanakkale Boğazı

\section{INTRODUCTION}

Seawater, which forms oceans and seas, covers more than $70 \%$ of the earth's surface. Also, seawater is a mixture of $96.5 \%$ water, $2.5 \%$ salt and contains dissolved inorganic and organic substances and several atmospheric gases. Seawater is rich in elements (Sharp and Bryne et al., 2020). Elements reach the sea from various sources. These are divided into natural resources and anthropogenic resources. Natural resources include mineral deposits, erosion of soil and rocks, dust caused by wind, volcanic activities, atmospheric and forest fires. Those anthropogenic resources include waste products, household wastes, pesticides, mines, petroleum refineries, protective paints, which are formed as a result of the use of elements and compounds in the industry (Ünsal, 2004). Elements that reach the seas from these sources are soluble in seawater or are present in the form of particles. Soluble ones are in the form of free metal ions or unstable organic and inorganic compounds (Çetingül and Aysel, 1998; Ünsal, 2004). Sea bottoms are areas of continuous sediment formation. Some of the sediments are materials transported by rivers, winds, and glaciers to the sea, and most of the sediments are the remains of marine creatures (Akkan, 1981). Aquatic organisms can take elements directly from the body surface and gills, as well as through digestion (Phillips and Rainbow, 1994; Bat and Raffaelli, 1998).

Lagoons are ecotones between freshwater, marine, and terrestrial biotopes (Ustaoğlu et al., 2012; Maanan et al., 
2015; Botello et al., 2018; Kükrer et al., 2020). Lagoons are connected to the sea via one or more canals. The water exchange with the sea and the transport of nutrients with it occur through tides, river flow, wind, and waves (Larson, 2012; Sevgi and Ulutarhan-Süzer, 2019). Due to the shallow transitional environments of lagoons such as rivers, streams, groundwaters and currents in lagoons, and also due to the influence of coastal geomorphological processes, hydrological processes, natural vegetation, and land use in the basin (Ustaoğlu et al., 2012), the physicochemical parameters frequently change. This affects the physiology and metal bioaccumulation in organisms distributed in lagoons (McLusky et al., 1986; Dame, 1996; Ulutarhan et al., 2019). Lagoons are among the most productive marine ecosystems in the world, serving as nutrition, habitat, migration routes, and nursery areas for many organisms such as phytoplankton, diatom, dinoflagellate, algae, fish, and bivalves (Din, 1992; Balls et al., 1997; Chapman and Wang, 2001). The Çardak lagoon chosen as a study area is abundant in terms of many economic fish species such as Mullet (Mugil sp.), Gilthead seabream (Sparus aurata), Scad (Trachurus sp.), Bluefish (Pomatomus saltatrix), eel fish (Anguilla sp.), picarel (Spicara smaris), common sole (Solea sp.), sparid fish (Sarpa salpa), striped sea bream (Lithognathus mormyrus), garfish (Belone belone), twaite shad (Livoneca punctata), flounder (Platichthys flesus) and bivalve species such as Mediterranean mussel (Mytilus galloprovincialis), manila clam (Ruditapes philippinarum), carpet shell clam, (Ruditapes decussatus), flat oyster (Ostrea edulis), razor clam (Ensis sp.), venerid clam (Venus gallina), lagoon cockle (Cerastoderma glaucum)(Vural and Acarlı, 2018).

Smooth scallop (Flexopecten glaber) is one of the bivalve organisms within the mollusks and is included in the Pectinidae order. F. glaber is distributed from the eastern Atlantic, Mediterranean, Black Sea, and Portugal to Morocco while in Turkey, it is seen as dense stocks from the south of Marmara, along the Aegean Sea, and throughout the Mediterranean (Aquamaps, 2019).

Bivalves are important marine organisms due to their nutritional value, taste, and reasonable selling prices (Orban et al., 2002; Orban et al., 2007). They have a rich nutritional composition, including high protein content, essential amino acids, low-fat content, high levels of $\omega 3$ fatty acids, elements, and antioxidants (Orban et al., 2002; Orban et al., 2007; Prato et al., 2019).

Microelements are accumulated in marine organisms (Plessi et al., 2001) and transferred to humans through the food chain (Gökoğlu et al., 2008). Microelements are especially of important in infants and children (WHO, 2006). Elements such as iron $(\mathrm{Fe})$, copper $(\mathrm{Cu})$, zinc $(\mathrm{Zn})$, and manganese $(\mathrm{Mn})$ are essential elements as they play an important role in biological systems (Hogstrand and Haux, 1991), however, their excessive consumption is toxic (Tarley et al., 2001). Generally, bivalves accumulate certain elements, especially zinc (Lök et al., 2010). Storelli et al. (2000) have reported that mollusks have a higher amount of $\mathrm{Zn}$ compared to fish species found in the Mediterranean. Manthey-Karl et al. (2015) have reported that smooth scallop meat is a good source of $\mathrm{Zn}$. El Shenawy et al. (2016) observed that $\mathrm{Al}$ is dominant in sediments and bivalves. In humans, an average of $4 \%$ aluminum (Al) taken with nutrition is absorbed by the intestines and accumulates in bones, liver, lung, thyroid glands, and brain (Hellström-Westas and Rosen, 2006).

Sodium (Na), Magnesium (Mg), Potassium (K), Calcium (Ca), Phosphorus $(\mathrm{P})$, and Sulfur $(\mathrm{S})$ are macro elements. $\mathrm{Na}$ is an important element in the regulation of osmotic pressure (Tapiero et al., 2003; Yaşar and Melek, 2003), stimulation of nerves, and continuity of nerve and muscle functions. Also, $\mathrm{Na}$ plays a role in bone development together with $\mathrm{Ca}$. Bivalves contain higher levels of $\mathrm{Na}$ than fish species (Spanish mackerel, Gray eel-catfish, Longtail shad; Cuttlefish, Prawn) (Nurnadia et al., 2013), while sea species contain higher levels of $\mathrm{Na}$ than freshwater species (Sidwell et al., 1977). $\mathrm{K}$ is one of the vital elements for humans. Of the $\mathrm{K}$ in the body, $98 \%$ is found inside the cell walls. $K$, together with $\mathrm{Na}$, is responsible for the water balance in the body, in the passage of food into the cell, in the transmission of messages in the nervous system, in the formation of tissues such as bones, teeth, red blood cells, and muscles, and it maintains the healthy structure of the heart and other muscles. Also, $\mathrm{K}$ has beneficial effects in the development of bones together with Ca (Karadeniz, 2004, İnan and Gül, 2001; Cashman, 2006). It was determined that the macro element with the highest ratio in smooth scallop meat is usually $\mathrm{K}$ (Bilandzic et al., 2015, Manthey-Karl et al., 2015).

There are studies $n$ the elemental composition of smooth scallop meat (Özden and Erkan, 2011; Berik et al., 2017; Prato et al., 2019a; Prato et al., 2019b). However, studies on the monthly element composition are limited (Prato et al., 2019a). Therefore, the present study aimed to monthly determine the element content of the meat of smooth scallop ( $F$. glaber), one of the economic bivalves collected from the Çanakkale Strait Çardak lagoon in the Turkish Straits System, and also to determine its compliance with the maximum limits 
determined by health organizations. In addition, in this study, it was aimed to evaluate the potential health risk that may occur in case of consumption by adults by determining the Target Hazard Quotient (THQ) and Hazard Index (HI) values for the general population, taking into account the consumption frequency of the smooth scallop.

\section{MATERIAL AND METHODS}

Smooth scallop samples (53.95 $\pm 3.70 \mathrm{~mm}$ in length) were collected by hand monthly between July 2017 and June 2018 in the Canakkale Province, Lapseki district, Çardak Lagoon in Turkey, (40² $\left.22^{\prime} 56^{\prime \prime} \mathrm{N}, 21^{\circ} 42^{\prime} 58^{\prime \prime} \mathrm{E}\right)$ (Figure 1). Çardak lagoon consists of 3 parts: Burunucu lagoon, Buruniçi lagoon and Ortagöl. The lagoon is a 180 ha saltwater lagoon located near the village of Çardak (Lapseki-Canakkale) on the southern coast of Marmara Sea. It is a lagoon with an average depth of $1.5 \mathrm{~m}$ (GTHB, 1997). The lagoon is under the influence of the sea, with its deep and open passage. There are many fish and bivalve species in the lagoon. Throughout the study, 30 smooth scallops per month were brought to the laboratory. Fouling organisms adhering on the smooth scallops were removed using a knife and the meat content of the smooth scallop was freeze dried after seperating the meat from the shell parts.

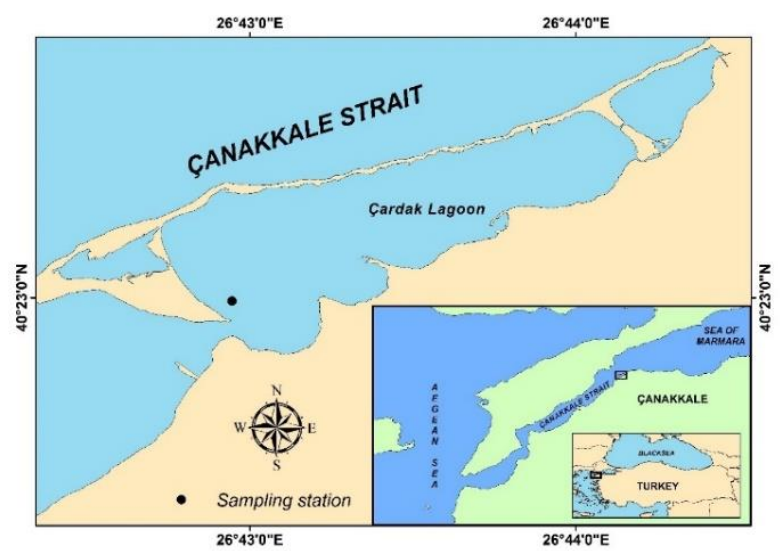

Figure 1. Map showing the sampling area Çardak Lagoon

A $0.5 \mathrm{~g}$ of dry smooth scallop meat and $10 \mathrm{ml}$ of $\mathrm{HNO}_{3}$ mixture were dissolved by burning in a microwave incinerator. It was then allowed to cool and filtered with distilled water. SpectroBlue inductively coupled plasma optical emission spectrometry (ICP-OES) was used to measure the element concentrations in smooth scallop meat after closed-vessel microwave digestion (EPA, 1994). Element content was expressed as percent of dry weight (dw).

Freeze-dried meat of the scallops was used to determine the element compositions. The dry weight of element concentration $(\mathrm{mg} / \mathrm{g})$ was converted to wet weight using to calculate the hazard quotient (THQ) and hazard index (HI). A coefficient was used in the conversion to wet meat. In the calculation of this coefficient, the method of El-Shenawy et al. (2016) was used (Table 1).

Table 1. Conversion coefficients of freeze dried Flexopecten glaber meat to wet $F$. glaber meat.

\begin{tabular}{ll}
\hline Months & $\begin{array}{l}\text { Wet meat } \\
\text { converison coefficients }\end{array}$ \\
\hline July & 0.25 \\
August & 0.26 \\
September & 0.24 \\
October & 0.26 \\
November & 0.24 \\
December & 0.22 \\
January & 0.22 \\
February & 0.25 \\
March & 0.25 \\
April & 0.23 \\
May & 0.23 \\
June & 0.23 \\
\hline
\end{tabular}

The values of element in smooth scallop meat were used to calculate the estimated daily intake of elements (EDI), and target hazard quotients (THQ), hazard index $(\mathrm{HI})$ seperately for adult individuals. In this evaluation, $70 \mathrm{~kg}$ of body weight refers to adult people (Yaman et al. 2014). The bivalve consumption rate in Turkey in 2010 is $1 \mathrm{~g} /$ person day (FAO, 2010).

\section{Edible Daily Intake (EDI)}

The EDI value was calculated with the following equation (Javed and Usmani, 2016; Alkan et al., 2020; Tokatlı and Ustaoğlu, 2021):

$$
\mathrm{EDI}=\frac{\mathrm{C}_{\text {element }} \times \mathrm{D}_{\text {food intake }}}{\mathrm{BW}}
$$

Celement $=$ Element concentration in smooth scallop wet weight $(\mathrm{mg} / \mathrm{kg})$,

$D_{\text {food intake }}=$ Daily ingestion rate ( $\mathrm{kg} /$ person.day) $1 \mathrm{~g}$ for bivalve )

$\mathrm{BW}=$ Average body weight ( $70 \mathrm{~kg}$ for adults).

\section{Target Hazard Quotient (THQ)}

The $T H Q$ is an estimation of the non-carcinogenic risk level and is used in its calculation with the following equation (USEPA,2019a; 2019b):

$$
\mathrm{THQ}=\frac{\mathrm{EDI}}{\text { RfDo } \times \mathrm{AT}}
$$

RfD: Oral referans dose (mg/kg/day) (Table 2)

AT: Average exposure time for non-carcinogenic effects (365 days/year $x$ ED)

ED: Exposure duration (70 years for a person is assumed in this study, equivalent to the average lifetimes),

$\mathrm{HQ}$ is categorized into six classes: $H Q<1$ (no health risk); $1<H Q<1.5$ (low health risk); $1.5<H Q<2$ (medium-low health 
risk); $2<\mathrm{HQ}<2.5$ (medium risk); $2.5<\mathrm{HQ}<3$ (next higher risk); $3<\mathrm{HQ}$ (high risk) (USEPA, 1989; Çulha et al., 2016; Alkan et al., 2020).

\section{Hazard Index (HI)}

The $\mathrm{HI}$ can be calculated by the sum of the target hazard quotients of each metal (USEPA, 1989, 2011).

$$
\mathrm{HI}=\Sigma \mathrm{THQ}
$$

The significance of the monthly variations of element composition was determined using the one-way analysis of variance (ANOVA). Homogeneity of variance was determined using the Levene test. Investigation of the normality of data was carried out using the Kolmogorov-Smirnov test. Differences were analyzed using the post hoc Tukey test. Differences with values of $p<0.05$ were considered statistically significant.

The results were also examined using principal component analysis (PCA) using $R$ Version 3.6.1., in order to identify the element that most contributes to the monthly variations of element content. PCA-based Biplots (Gabriel, 1971) were made for each element separately. PCA transformed the raw data into unit-less variables and also distribute variability into different factors or principal components. Biplot was drawn by using principal factors, which have most of the variability. Biplot was two dimensional scatter diagram that depicted the scattering pattern of elements and months. The method has been used to display objects and variables on the same graph in principal components analysis, row and column factors in correspondence analysis of two-way contingency tables, and detect interaction in two-way analysis of variance tables (Gower and Hand, 1996). Proximity between elements or months may be gleaned from these types of plots. Also, it is commonly used to interpret the axes in the biplot and treat the coordinates as scores on these axes. In the correlation analysis graphs, dark colors indicate a very high relationship and red colors indicate a negative relationship. As the darkness of the color increases, the strength of the relationship increases. As the color approaches white, the contribution value approaches 0 .

\section{RESULTS}

The monthly changes in element concentrations are given in Table 2. The most abundant microelement was $\mathrm{Fe}$, followed by $\mathrm{Zn}, \mathrm{Mn}$, and Al. The average Fe value was $0.31 \pm 0.06 \mathrm{mg} / \mathrm{g}$ dry weight, $\mathrm{dw}(0.08 \pm 0.02 \mathrm{mg} / \mathrm{g}$ wet weight, $w w)$, the highest $\mathrm{Fe}$ value was measured in March whereas the lowest $\mathrm{Fe}$ value was measured in June, and a statistically significant difference was found between the months $(p<0.05)$. The average $Z n$ value was $0.11 \pm 0.02 \mathrm{mg} / \mathrm{g} \mathrm{dw}$ $(0.03 \pm 0.00 \mathrm{mg} / \mathrm{g} \mathrm{ww})$, and Zinc did not present clear temporal trends. Mn showed a statistically significant difference especially in March and June $(p<0.05)$. The average value of Al per month was found to be $0.04 \pm 0.02 \mathrm{mg} / \mathrm{g} \mathrm{dw}(0.01 \pm 0.00$ $\mathrm{mg} / \mathrm{g} \mathrm{ww}$ ). The average $B$ value was found to be $0.01 \mathrm{mg} / \mathrm{g}$ $\mathrm{dw}$ only in April and June, whereas $0.02 \mathrm{mg} / \mathrm{g} \mathrm{dw}$ in the other months, and there was a statistically significant difference between the months $(p<0.05)$. The average $\mathrm{Cu}$ value was $0.01 \pm 0.00 \mathrm{mg} / \mathrm{g} \mathrm{dw}(1.01 \pm 0.36 \mu \mathrm{g} / \mathrm{g} \mathrm{ww})$, and the difference between the months was statistically significant $(p<0.05)$. Selenium (Se) was detected in smooth scallop meat in trace levels $(0.01 \mathrm{mg} / \mathrm{g} \mathrm{dw}, 1.18 \mu \mathrm{g} / \mathrm{g} \mathrm{ww})$ only in December, and the differences between the months were significant $(p<0.05)$ (Table 2.)

Of the macro elements, $S$ was generally found to be low in winter and spring, whereas high in summer and autumn. It was observed that $\mathrm{Na}$ is usually high in summer and autumn, low in winter and spring, and statistically different between the months $(p<0.05)$. The lowest $K$ value was measured in April, whereas the highest value was measured in October. $P$ values varied in the range of $4.86-7.10 \mathrm{mg} / \mathrm{g} \mathrm{dw}(1.55 \pm 0.18$ $\mathrm{mg} / \mathrm{g} \mathrm{ww}$ ) during the study and the differences between the months were statistically significant $(p<0.05)$. The average value of $\mathrm{Mg}$ was $2.34 \pm 0.36 \mathrm{mg} / \mathrm{g} \mathrm{dw}(0.56 \pm 0.09 \mathrm{mg} / \mathrm{g} \mathrm{ww})$ and it varied between $1.64 \mathrm{mg} / \mathrm{g} \mathrm{dw}(0.38 \mathrm{mg} / \mathrm{g} \mathrm{ww})$ in April and $2.92 \mathrm{mg} / \mathrm{g} \mathrm{dw}(0.73 \mathrm{mg} / \mathrm{g} \mathrm{ww})$ in July and the difference was statistically significant $(p<0.05)$. The average value of $\mathrm{Ca}$ was $1.12 \pm 0.34 \mathrm{mg} / \mathrm{g} \mathrm{dw}(0.22 \pm 0.27 \mathrm{mg} / \mathrm{g} \mathrm{ww})$ and it varied between $0.61 \mathrm{mg} / \mathrm{g} \mathrm{dw}(0.15 \mathrm{mg} / \mathrm{g} \mathrm{ww})$ in March and 1.90 $\mathrm{mg} / \mathrm{g} \mathrm{dw}(0.48 \mathrm{mg} / \mathrm{g} \mathrm{ww})$ in July $(p<0.05)$. (Table 2.).

According to the correlation graph of the elements, negatively correlated were found between $\mathrm{B}$ and $\mathrm{Fe}, \mathrm{Se}$ and $\mathrm{Mn}, \mathrm{Al}$ and $\mathrm{Fe}, \mathrm{Mn}, \mathrm{S}$ and $\mathrm{Ca}$. A positively correlated was observed between other elements (Figure 2).

There were three dimensions with $\geq 1$ according to their eigen values. This showed that three dimensions will be sufficient to explain all elements (Table 3. )

According to the graph of the percentage of variances that can be explained, the elements were examined in four dimensions. Among these four dimensions, the first dimension explained $58.7 \%$ of the variances, while the second dimension explained $17.92 \%$ (Figure 3). Therefore, examining the first and the second dimensions (since it explained $76.62 \%$ of the variances) was sufficient for the evaluation of all elements. 
Monthly variation of micro- and macro-element composition in smooth scallop, Flexopecten glaber (Linnaeus, 1758), from the Çardak Lagoon (Çanakkale Strait, Turkey)

Table 2. Monthly variation of element composition in smooth scallop $(\mathrm{mg} / \mathrm{g} \mathrm{dw})^{\prime}$

\begin{tabular}{|c|c|c|c|c|c|c|c|c|c|c|c|c|}
\hline Element & Jul. & Aug. & Sep. & Oct. & Nov. & Dec. & Jan. & Feb. & Mar. & Apr. & May & Jun. \\
\hline \multicolumn{13}{|c|}{ Microelement } \\
\hline $\mathrm{Fe}$ & $0.39 \mathrm{~cd}$ & $0.33^{\mathrm{abcd}}$ & $0.32^{\mathrm{abcd}}$ & $0.32^{\mathrm{abcd}}$ & $0.29 \mathrm{abcd}$ & $0.37^{\mathrm{bcd}}$ & $0.29 \mathrm{abcd}$ & $0.28 \mathrm{abc}$ & $0.20^{a}$ & $0.23^{a b}$ & $0.34^{\mathrm{abcd}}$ & $0.43^{d}$ \\
\hline $\mathrm{Cu}$ & 0.01 & 0.01 & 0.01 & 0.01 & 0.01 & 0.01 & ND & 0.01 & 0.01 & ND & 0.01 & ND \\
\hline $\mathrm{Mn}$ & $0.11 \mathrm{~g}$ & $0.07_{\text {def }}$ & $0.06^{\text {bcdef }}$ & $0.05^{\text {bcde }}$ & $0.08^{\text {efg }}$ & $0.05^{\text {bcde }}$ & $0.03^{a b}$ & $0.04^{\mathrm{bcd}}$ & $0.01^{a}$ & $0.03^{a b c}$ & $0.07_{\text {cdef }}$ & $0.08^{f g}$ \\
\hline $\mathrm{Zn}$ & 0.12 & 0.09 & 0.10 & 0.11 & 0.13 & 0.13 & 0.12 & 0.11 & 0.10 & 0.08 & 0.12 & 0.10 \\
\hline $\mathrm{Al}$ & $0.02^{a b c}$ & $0.03^{\text {bcde }}$ & $0.04^{\mathrm{de}}$ & $0.03^{\text {cde }}$ & $0.03 b^{c d}$ & $0.05^{f}$ & $0.08 \mathrm{~g}$ & $0.07 \mathrm{~g}$ & $0.04 \mathrm{ef}^{\mathrm{f}}$ & $0.01^{a}$ & 0.04 cde & $0.02^{\mathrm{ab}}$ \\
\hline $\mathrm{Se}$ & ND & ND & ND & ND & ND & 0.01 & ND & ND & ND & ND & ND & ND \\
\hline $\mathrm{B}$ & 0.02 & 0.02 & 0.02 & 0.02 & 0.02 & 0.02 & 0.02 & 0.02 & 0.02 & 0.01 & 0.02 & 0.01 \\
\hline \multicolumn{13}{|c|}{ Macroelement } \\
\hline $\mathrm{Na}$ & $16.98^{d e}$ & $15.69 \mathrm{bcde}$ & 16.11 bcde & $16.31^{\text {cde }}$ & $15.27^{\text {bcde }}$ & $18.79 \mathrm{e}$ & $13.12^{\text {abcde }}$ & $10.97 \mathrm{abc}$ & $10.37^{a b}$ & $9.39 a$ & 13.70abcde & $12.25^{\mathrm{abcc}}$ \\
\hline $\mathrm{Mg}$ & $2.92^{c}$ & $2.38^{a b c}$ & $2.47 \mathrm{abc}$ & $2.47^{a b c}$ & $2.35^{a b c}$ & $2.80 b^{c}$ & $2.56^{a b c}$ & $2.10^{a b c}$ & $1.91^{a b}$ & $1.64^{a}$ & $2.30^{a b c}$ & $2.14 \mathrm{abc}$ \\
\hline K & 13.63 & 12.17 & 12.76 & 14.44 & 13.08 & 13.42 & 11.38 & 10.48 & 10.59 & 8.04 & 10.61 & 10.31 \\
\hline $\mathrm{Ca}$ & $1.90^{b}$ & $1.37^{a b}$ & $1.10^{a b}$ & $1.33^{a b}$ & $1.09^{a}$ & $1.37^{a b}$ & $0.96^{a}$ & $1.01^{a}$ & $0.61^{a}$ & $0.72^{a}$ & $1.06^{a}$ & $0.96^{a}$ \\
\hline$P$ & 6.92 & 6.40 & 6.82 & 6.63 & 6.51 & 6.55 & 6.65 & 6.23 & 7.10 & 4.86 & 6.93 & 5.98 \\
\hline$S$ & 35.01 & 28.22 & 30.85 & 33.66 & 30.86 & 30.67 & 7.10 & 6.53 & 6.30 & 5.35 & 6.98 & 7.25 \\
\hline
\end{tabular}

${ }^{1}$ Different superscript letters within rows represent significant differences $(p<0.05)$ based on results of the post hoc Tukey test.

${ }^{2}$ N.D.: Not detected.

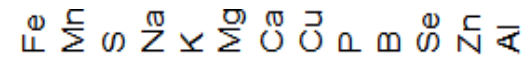

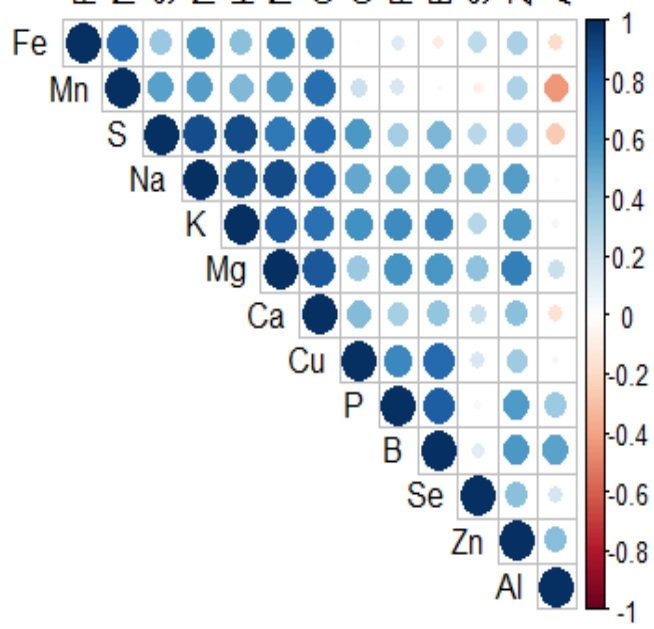

Figure 2. Correlation plot of elements ( $\mathrm{Fe}, \mathrm{Mn}, \mathrm{Cu}, \mathrm{B}, \mathrm{Se}, \mathrm{Zn}, \mathrm{Al}, \mathrm{P}$, $\mathrm{S}, \mathrm{Na}, \mathrm{K}, \mathrm{Mg}$, and $\mathrm{Ca}$ )
Table 3. Eigen value of elements ( $\mathrm{Fe}, \mathrm{Mn}, \mathrm{Cu}, \mathrm{B}, \mathrm{Se}, \mathrm{Zn}, \mathrm{Al}, \mathrm{P}, \mathrm{S}$, $\mathrm{Na}, \mathrm{K}, \mathrm{Mg}$, and $\mathrm{Ca}$ )

\begin{tabular}{lccc}
\hline & Eigen Value & Variance (\%) & Cumulative Variance (\%) \\
& & & \\
\hline Dimension 1 & 5.81 & 48.39 & 48.39 \\
Dimension 2 & 2.52 & 21.02 & 69.41 \\
Dimension 3 & 1.36 & 11.35 & 80.76 \\
Dimension 4 & 0.96 & 7.97 & 88.72 \\
Dimension 5 & 0.48 & 4.00 & 92.73 \\
Dimension 6 & 0.35 & 2.89 & 95.61 \\
Dimension 7 & 0.30 & 2.50 & 98.11 \\
Dimension 8 & 0.15 & 1.24 & 99.35 \\
Dimension 9 & 0.06 & 0.51 & 99.86 \\
Dimension 10 & 0.01 & 0.10 & 99.96 \\
Dimension 11 & 0.00 & 0.04 & 100.00 \\
\hline
\end{tabular}




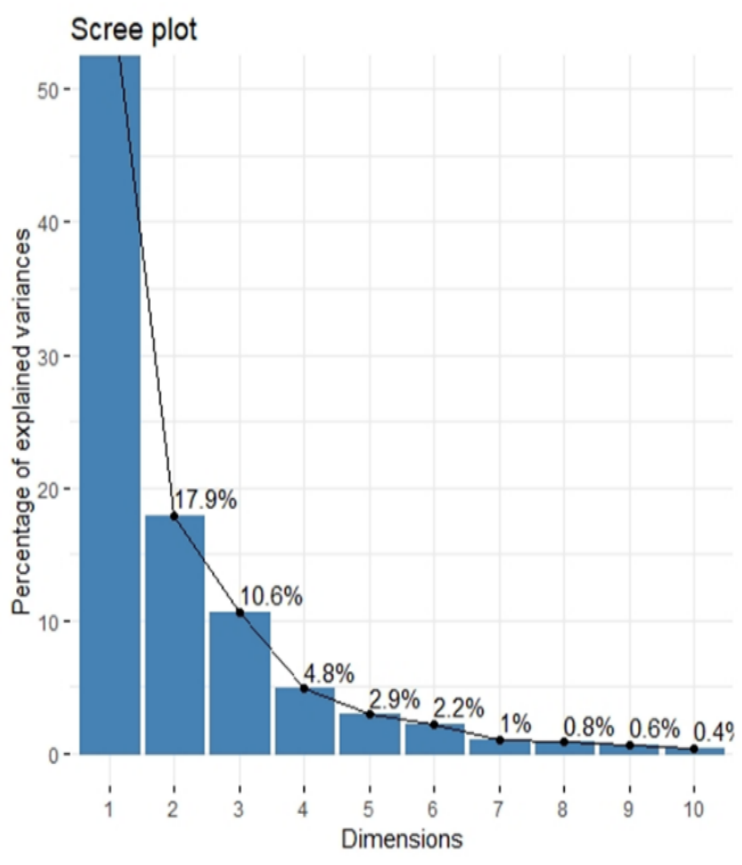

Figure 3. Percentage of explained variances of elements $(\mathrm{Fe}, \mathrm{Mn}$, $\mathrm{Cu}, \mathrm{B}, \mathrm{Se}, \mathrm{Zn}, \mathrm{Al}, \mathrm{P}, \mathrm{S}, \mathrm{Na}, \mathrm{K}, \mathrm{Mg}$ and $\mathrm{Ca}$ )

According to the biplot graph, the contribution of $\mathrm{Na}, \mathrm{Mg}$, $\mathrm{K}, \mathrm{Ca}, \mathrm{S}, \mathrm{B}$ elements were higher at Dimension 1. Furthermore, $\mathrm{Al}, \mathrm{Mn}, \mathrm{B}$, and $\mathrm{Fe}$ elements among other elements were higher at Dimension 2. There were proximity were observed in May with Al, August with Fe, Mn, October with $\mathrm{Se}, \mathrm{Zn}, \mathrm{Cu}, \mathrm{P}$, December with K, October and November with $\mathrm{Ca}, \mathrm{S}, \mathrm{Na}$, and $\mathrm{Mg}$ (Figure 4).

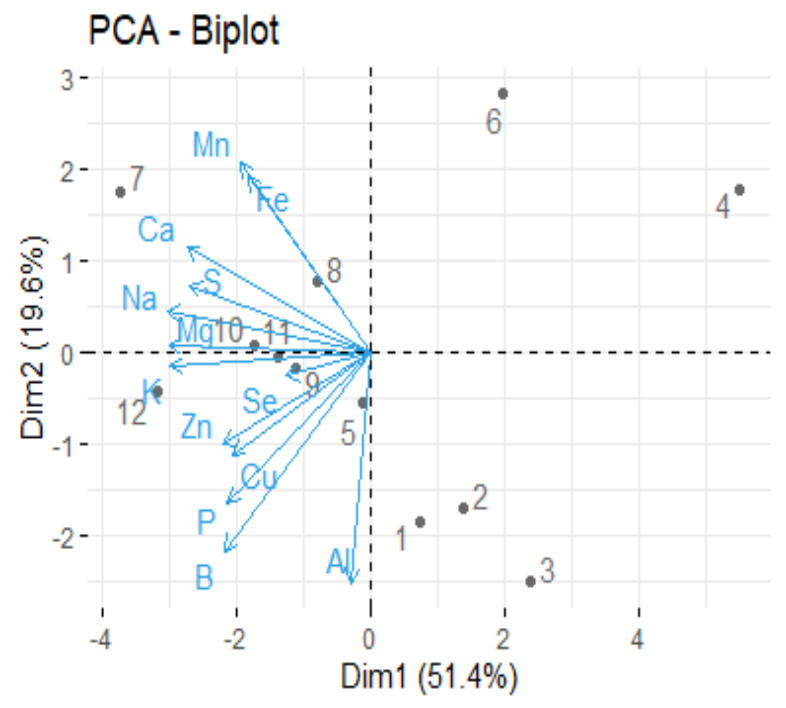

Figure 4. Principal component analysis (PCA)-Biplot of the composition of element values ( $\mathrm{Fe}, \mathrm{Mn}, \mathrm{Cu}, \mathrm{B}, \mathrm{Se}, \mathrm{Zn}, \mathrm{Al}, \mathrm{P}, \mathrm{S}, \mathrm{Na}$, $\mathrm{K}, \mathrm{Mg}$ and $\mathrm{Ca}, 1: J a n u a r y, 2:$ February,3:March,4: April, 5: May, 6: June, 7:July,8:August, 9: September, 10: October, 11: November, 12: December).
THQ and $H$ values were used to determine the noncarcinogenic health risks posed by the elements in the consumption of smooth scallops. The THQ and $\mathrm{HI}$ values of the smooth scallop are given in Table 4. THQ and $\mathrm{HI}$ values below 1 in all months throughout the year, confirmed that continuous consumption of smooth scallop for 70 years had no adverse effects on human health.

Table 4. Rererence dose (Rfd), Estimated daily intake (EDI), Target hazard quotient (THQ) and Hazard index (HI) values of elements via consumption of smooth scallop

\begin{tabular}{llll}
\hline Elements & $\begin{array}{l}\text { RfD } \\
\text { (mg/kg bw-day) }\end{array}$ & $\begin{array}{l}\text { EDI of smooth scallop } \\
\text { (mg/70 } \mathrm{kg} \text { bw-day) }\end{array}$ & $\begin{array}{l}\text { THQ of smooth } \\
\text { scallop }\end{array}$ \\
\hline $\mathrm{Na}$ & $2 \times 10^{3}$ & $4.83 \times 10^{-5}$ & $6.17 \times 10^{-4}$ \\
$\mathrm{Mg}$ & $3.5 \times 10^{2}$ & $8.01 \times 10^{-6}$ & $5.85 \times 10^{-4}$ \\
$\mathrm{~K}$ & $2 \times 10^{3}$ & $4.04 \times 10^{-5}$ & $5.16 \times 10^{-4}$ \\
$\mathrm{Ca}$ & $8 \times 10^{2}$ & $3.87 \times 10^{-6}$ & $1.24 \times 10^{-4}$ \\
$\mathrm{P}$ & $3 \times 10^{2}$ & $2.22 \times 10^{-5}$ & $1.89 \times 10^{-3}$ \\
$\mathrm{Fe}$ & $7 \times 10^{-1}$ & $1.08 \times 10^{-6}$ & $3.93 \times 10^{-2}$ \\
$\mathrm{Cu}$ & $4 \times 10^{-2}$ & $2.16 \times 10^{-8}$ & $1.38 \times 10^{-2}$ \\
$\mathrm{Mn}$ & $1.4 \times 10^{-1}$ & $1.93 \times 10^{-7}$ & $3.53 \times 10^{-2}$ \\
$\mathrm{Zn}$ & $3 \times 10^{-1}$ & $3.77 \times 10^{-7}$ & $3.21 \times 10^{-2}$ \\
$\mathrm{Al}$ & 1 & $1.28 \times 10^{-7}$ & $3.27 \times 10^{-3}$ \\
$\mathrm{Se}$ & $5 \times 10^{-3}$ & $1.14 \times 10^{-8}$ & $5.83 \times 10^{-2}$ \\
$\mathrm{~B}$ & $2 \times 10^{-1}$ & $5.9 \times 10^{-8}$ & $7.54 \times 10^{-3}$ \\
$\mathrm{EHI}$ & & & 0.19 \\
\hline
\end{tabular}

Rfd value data taken from WHO (2012), FAO/WHO (1993, 2002, 2010), Aksoy (2014), USEPA (2019a).

\section{DISCUSSION}

Bivalves taking elements not only from water and food but also from inorganic particles they digest (Warnau et al., 1996; El-Sikaily et al., 2004). However, even though they are in the same region, the element contents in bivalves may differ. Differences in element levels in bivalves depend on the bioaccumulation capacity of each species, physiological conditions (reproductive activity, growth, filtration rate), biotic factors (age, height, and sex), genetic characteristics, abiotic factors (salinity, $\mathrm{pH}$, temperature, and dissolved oxygen) depends on the chemical form of the elements, the structure of the sediment, and the area (O'Connor, 1996; Mendez et al., 2001; Skinner et al., 2004; Fuentes et al., 2009; Ulutarhan et al., 2019).

In humans, $\mathrm{Fe}$ has several vital functions including transporting $\mathrm{O}_{2}$ to tissues via the red blood cells hemoglobins, being a transport medium for electrons in cells, and being a part of important enzyme systems in various tissues (FAO/WHO, 2002). Fe is found in pigments (hemoglobin) that are found in the blood of many vertebrate and invertebrate organisms and carry oxygen and carbon dioxide for cell respiration (Clark, 1992). The increase in Fe concentrations are an indicator of the field's nutrient flow (drawdown), 
phytoplankton biomass, productivity (Fitzwater et al., 2000). Fe deficiency is seen in more than two million people around the world (Stoltzfus and Dreyfuss, 1998). Different consumption values are recommended for Fe based on the criteria including age, gender, etc. There is $300 \mathrm{mg}$ Fe stored in the body, and $1 \mathrm{mg} / \mathrm{day} \mathrm{Fe}$ in men, and $1.5 \mathrm{mg} / \mathrm{day}$ in women are excreted from the body (Aksoy, 2014). It is recommended to take $10 \mathrm{mg}$ Fe for adult men and $15 \mathrm{mg} / \mathrm{day}$ for women. Fe intake is recommended as $15 \mathrm{mg} /$ day (Aksoy, 2014) during pregnancy and breastfeeding, $11 \mathrm{mg} /$ day for 0.5-1 year-olds (Schümann et al., 2007), $10 \mathrm{mg} /$ day for babies and children from 6 months to 3 years (Aksoy, 2014). In the present study, the Fe values in smooth scallop were lower than those reported in the previous studies (Orban et al., 2007; Periyasamy et al., 2014).

Cu plays an important role in the functioning of various enzymes (Bajgas, 2000; Hambidge, 2000), carbohydrate metabolism, photosynthesis (Bajgas, 2000). It is also essential for the circulatory system (Walker et al., 2002). So it has to be consumed by humans, fish, bivalves, and other aquatic creatures (FAO/WHO, 2004). Excessive $\mathrm{Cu}$ has a toxic effect on the body and prevents the functions of some enzymes (Bajgas, 2000). FAO/WHO (2004) and USEPA (2019) temporarily determined the edible daily intake (EDI) as $0.4 \mathrm{mg} / \mathrm{kg} /$ day. The $\mathrm{Cu}$ value found in the present study was below the limits determined by FAO/WHO (2004). It was thought that consuming $42.85 \mathrm{~g}$ smooth scallop daily will meet the amount recommended by FAO/WHO (2004) and USEPA (2019). Also, the $\mathrm{Cu}$ levels decrease when industrial and urban emissions, fertilizers, algaecides, fungicides, molluscicides, cyanobacteria in the region decrease (Moffett et al., 1997; Besada et al., 2002; Cheriyan et al., 2015). Cu is found in the greenish-blue pigment (hemocyanin) that carries oxygen of mollusks and crustaceans (Clark, 1992). The amount of influx and efflux of $\mathrm{Cu}$ element in bivalves vary among species (Cai and Wang, 2019).

The dissolved concentration of $\mathrm{Zn}$ in seawater ranges around $<0.1 \mathrm{nmol} / \mathrm{kg}$ in surface waters. $\mathrm{Zn}$ plays a role in the synthesis of some enzymes that affect $\mathrm{CO}_{2}$ and $\mathrm{P}$ uptake, photosynthesis, phytoplankton growth and microalgal growth, and the catabolism of carbohydrate, fat, protein, and nucleic acids (Morel et al., 1994; Bajgas, 2000; FAO/WHO, 2002; Shaked et al., 2006; Shariati and Yahyaabadi, 2006). In the present study, the $\mathrm{Zn}$ value was found to be lower than those in P. maximus (12.6-16.9 mg/kg wet meat) (Manthey-Karl et al., 2015), D. incarnatus (0.34 mg/g dry meat) (Periyasamy et al., 2014), and C. gallina (0.91-1.48 mg/ $100 \mathrm{~g}$ wet meat) (Orban et al., 2007). Since $\mathrm{Zn}$ is an essential element observed in the cell wall of bacteria and diatoms, the death or decay of these microorganisms increases the amount of this element in the upwelling zone where coastal water and seawater are mixed (Lewis and Luther III, 2000; Monteiro and Roychoudhury, 2005; Baines et al., 2016; Grasse et al., 2016). In the present study, $\mathrm{Zn}$ values of smooth scallop were found to be safe for human consumption. Based on
$\mathrm{FAO} / \mathrm{WHO}$ (2004), it can be thought that consuming at max $350 \mathrm{~g}$ per week ( $7 \mathrm{~g}$ per day) would be sufficient.

The daily Al consumption should be $4-9 \mathrm{mg}$ (HellströmWestas and Rosen, 2006). The tolerable daily intake has been reported as $1 \mathrm{mg} / \mathrm{kg}$ body weight (WHO,1996, USEPA, 2019). Examining the values found in the present study, consuming $50 \mathrm{~g}$ per week $(7 \mathrm{~g}$ per day) of the smooth scallop collected from the Çardak Lagoon is within the limits determined by EFSA (2013)

$\mathrm{Se}$ is an essential micronutrient with selenoproteins that perform various metabolic functions in animals and humans (Wen and Hu, 2010; Rayman, 2020). Many of the selenoproteins affect antioxidant metabolism (Steinbrenner et al., 2016). Se plays a role in protection from infections, promotes growth and development (FAO/WHO, 2002). Thyroid dysfunction may occur in Se deficiency. The Se concentration in the blood should be $60-100 \mu$. Chronic high consumption of Se can cause changes in nail morphology, hair loss, diarrhea, central nervous system disorders, anorexia, kidney and liver damage (Selinus et al., 2005). The Se values in sediments and living things in the world vary due to different environmental conditions and agricultural practices (FAO/WHO, 2002). A daily intake of $55-75 \mu \mathrm{g}$ Se is recommended (Aksoy, 2014). In the present study, Se was detected in trace levels in smooth scallop meat only in December and below the detection limit in other months. Therefore, it can be argued that consuming $5.5-7.5 \mathrm{~g}$ of smooth scallops per day from the Çardak Lagoon during December will meet the daily requirement.

Turkey ranks first in the world in the $B$ source (Yiğitbaşıoğlu, 2004). B can be obtained from both foods and water. Evaluating the $\mathrm{B}$ element together with $\mathrm{Ca}, \mathrm{P}$, and $\mathrm{Mg}$ elements, contributes to the protection of vitamin $D$ in the body (sufficient quantity of boron prevents vitamin $D$ deficiency and, hence, osteoporosis and weakening and breaking of the bones) (Yakıncı and Kök, 2016). The B element is also effective in preventing the loss of $\mathrm{Ca}$ element in the body and in the transport of $\mathrm{Ca}$ element between cells (Aksoy, 2014). In the present study, a positively correlated was found between $\mathrm{Ca}$ and $\mathrm{B}(\mathrm{p}<0.05)$. For adults, a daily intake of $0.4-0.5 \mathrm{mg} / \mathrm{kg}$ body weight $B$ is recommended ( CODEX, 2007). In line with the results obtained from the present study, it can be argued that the smooth scallop in the lagoon contains $B$ elements throughout the year, and consuming $40 \mathrm{~g}$ smooth scallop per day will be sufficient to meet the $B$ requirement.

Although the presence of 77 elements in seawater was detected, only 7-8 of them were abundant. In order of abundance, these elements are $\mathrm{Cl}, \mathrm{Na}, \mathrm{Mg}, \mathrm{S}, \mathrm{Ca}, \mathrm{K}, \mathrm{Br}$, and C (Bat et al., 1998). In the present study, it was observed that the elements contained in the flesh of the smooth scallop were in a similar order except for sulfur. The anoxic nature of 
sedimentary affects the amount of sulfur in the water column (Büyükateş, 2017). In the present study, it can be argued that the high values of sulfur in the spring and summer months when the temperature increased was associated with the fact that the sediment was anoxic and, as a result, the water column was affected by this situation. In other words, the water properties of the environment may have affected the sulfur content of the smooth scallop.

In the present study, the $\mathrm{Mg}$ values in smooth scallop were much lower than those in P. maximus $(330-356 \mathrm{mg} / \mathrm{kg}$ ww) (Manthey-Karl et al., 2015), C. gallina (74.3-89.4 $\mathrm{mg} / 100 \mathrm{~g} \mathrm{ww}$ ) (Orban et al., 2007), and D. incarnatus (60.54 $\mathrm{mg} / \mathrm{g} \mathrm{dw}$ ) (Periyasamy et al., 2014). Mg is found in shell formation in small amounts as Mg-calcite (Broadaway, 2012). In the present study, it can be argued that the $\mathrm{Mg}$ in the smooth scallop will decrease due to its contribution to the shell growth in the spring. Evaluating in terms of nutrition, the daily recommended consumption is $350 \mathrm{mg}$ for men and 280 mg for women (Aksoy, 2014). It can be argued that it would be sufficient to consume $500-628 \mathrm{~g}$ smooth scallop per day purchased from the Çardak Lagoon to meet this amount.

As a result of the death of organisms, a significant part of organic $P$ dissolved or in particulate form in seawater turns into inorganic phosphate with the effect of phytoplankton species, the remaining part turns into inorganic phosphate by bacteria and this inorganic $P$ turns into organic matter that phytoplankton and other marine creatures can benefit from (Karl et al., 1995; Geldiay and Kocataş, 1988; ÇŞB, 2020). Although $P$ in seawater is maximum in summer, it was observed to decrease in autumn and reach a minimum level in the winter months. However, it was concluded that these changes depend on the regions (Geldiay and Kocataş, 1988). In the present study, although the $P$ value in smooth scallop was stable, it was generally the lowest in spring whereas highest in autumn. Also, the results obtained in the present study were similar to those reported by Orban et al. (2007) for C. gallina (108-177 mg/100g wet meat). The recommended daily $P$ consumption is $300-500 \mathrm{mg}$ (Aksoy, 2014). Therefore, it can be argued that consuming 300-500 g smooth scallop per day in the present study will meet the $P$ requirement.

$\mathrm{Ca}$ is of importance since it provides rigidity to the skeleton and plays an important role in many metabolic processes (FAO/WHO, 2002). Smooth scallop's shell consists of $\mathrm{CaCO}_{3}$. In the present study, one of the reasons for the decrease in this element in spring may be the contribution of $\mathrm{Ca}$ to the shell formation. Ca value determined in smooth scallop in the present study was lower than those reported in previous studies (Orban et al., 2007; Manthey-Karl et al., 2015). In terms of human consumption, the daily requirement is recommended as $800 \mathrm{mg}$, and this value increases to 1200 mg for pregnant and breastfeeding women (Aksoy, 2014). In general, it can be recommended to consume daily $2 \mathrm{~kg}$ of smooth scallop in the Çardak Lagoon. In previous studies, it was stated that the macro element with the highest value in smooth scallop meat is usually the K element (Bilandzic et al.,
2015, Manthey-Karl et al., 2015). The values found in this study were lower than the values found for $P$. maximus (3860$4118 \mathrm{mg} / \mathrm{kg}$ wet meat) (Manthey-Karl et al., 2015), C. gallina (221-257 mg/100g wet meat) (Orban et al., 2007), D. incarnatus (20.36 mg/g dry meat) (Periyasamy et al., 2014). The daily recommended $\mathrm{K}$ consumption for a healthy nervous system and a steady heart rhythm is $2000 \mathrm{mg}$ (Aksoy, 2014). In this study, it can be recommended to consume $167 \mathrm{~g}$ of smooth scallop per day to meet the amount needed. The $\mathrm{Na}$ values obtained in the present study were higher than those reported in the previous studies (Orban et al., 2007; MantheyKarl et al., 2015), however, the values exhibited a similar pattern of change during the year (Orban et al., 2007). The recommended daily minimum $\mathrm{Na}$ consumption is $500 \mathrm{mg}$ (Aksoy, 2014) and the maximum recommended value is $2 \mathrm{~g}$ (WHO, 2012). According to the Na values in this study, it was thought that consuming $167 \mathrm{~g}$ of smooth scallop meat per day, especially in autumn and summer, will meet the daily $\mathrm{Na}$ amount required. $\mathrm{Mn}$ is one of the vital microelements. It is also a structural component of some enzymes (Wen and Hu, 2010). Considering the Mn values determined in the present study, the consumption of 13-33 g smooth scallop is within the limits determined by CODEX (2007).

\section{CONCLUSION}

The results obtained in the present study provide valuable information for both smooth scallop breeders and the consumers. For smooth scallop consumers, the data obtained from the present study can be a guide for the months, and consumption amounts for the smooth scallop in this region. Since the smooth scallop in Çardak Lagoon meets the criteria set by the Ministry of Agriculture and Forestry in terms of element composition, its cultivation is recommended in this region.

It was observed that $F$. glaber individuals collected from Çardak Lagoon were suitable for consumption in terms of their element content. Also, in the present study, the heavy metal content of smooth scallop meat was below the limit values specified by organizations such as the Turkish Food Codex, WHO, FAO, etc. In addition, the fact that the THQ and $\mathrm{HI}$ values of the smooth scallop were below 1 in all months throughout the year confirmed that their consumption did not have a negative effect on human health.

\section{ACKNOWLEDGEMENTS}

This study was supported by Çanakkale Onsekiz Mart University The Scientific Research Coordination Unit, Project number: FDK/1349. We would like to thank Asst. Prof. Dr. Burcu Mestav, who contributed to the statistical analysis of this article. We would also like to thank Assoc. Prof. Dr.Bayram Kızılkaya and Assoc. Prof. Dr. Semih KALE for their valuable comments. Lab experiments were carried out in the laboratory of Biochemistry, and the laboratory of Feed and Food Analysis, Faculty of Marine Sciences and Technology, Çanakkale Onsekiz Mart University. 


\section{REFERENCE}

Akkan, E. (1981). Okyanusların mineral varlıkları. Coğrafya Araştırmaları Dergisi, 10, 91-100.

Aksoy, M. (2014). Beslenme biyokimyası. Ankara: Hatiboğlu Yayınları.

Aquamaps,(2019)

https://www.aquamaps.org/receive.php?type_of_map=regular Retrieved from 15.03.2019

Alkan, N., Alkan, A., Demirak, A. \& Bahloul, M. (2020). Metals/metalloid in Marine Sediments, Bioaccumulating in Macroalgae and a Mussel. Soil and Sediment Contamination: An International Journal, 29(5), 569-594. DOI:10.1080/15320383.2020.1751061

Baines, S. B., Chen, X., Vogt, S., Fisher, N. S., Twining, B. S. \& Landry, M. R. (2016). Microplankton trace element contents: Implications for minera limitation of mesozooplankton in an HNLC area. Journal of Plankton Research, 38, 256-270. DOI:10.1093/plankt/fbv109

Bajgas, A. (2000). Blocked of heavy metals accumulation in Chlorella vulgaris cells by 24- epibrassinolide. Plant Physiology and Biochemistry, 38, 797801. DOI:10.1016/S0981-9428(00)01185-2

Balls, P. W., Hull, S., Miller, B. S., Pirie, J. M. \& Proctor, W. (1997). Trace metal in Scottish estuarine and coastal sediments. Marine Pollution Bulletin, 34 (1), 42-50. DOI:10.1016/S0025-326X(96)00056-2

Bat, L. \& Raffaelli, D. (1998). Survival and growth of Corophium volutator in organically enriched sediment: A comparison of laboratory and field experiments. Turkish Journal of Zoology, 22 (3), 219-229.

Berik, N., Çankırılıgil, E.C. \& Gül, G. (2017). Mineral content of smooth scallop (Flexopecten glaber) caught Çanakkale, Turkey and evaluation in terms of food safety. Journal of Trace Elements in Medicine and Biology, 42, 97-102. DOl:10.1016/j.jtemb.2017.04.011

Besada, V., Fumega, J. \& Vaamonde, A. (2002). Temporal Trends of Cd, Cu, $\mathrm{Hg}, \mathrm{Pb}$ and $\mathrm{Zn}$ in mussel (Mytilus galloprovincialis) from the Spanish North- Atlantic Coast 1991- 1999. Science of the Total Environment, 288 (3), 239-253. DOI:10.1016/S0048-9697(01)01010-5

Bilandžić, N., Sedak, M., Čalopek, B., Đokić, M., Kolanović, B. S., Varenina, I., Božić, Đ., Varga, I., Đafić, N., Mišetić, D., Zrnčić, S. \& Oraić, D. (2015). Differences in element contents of shellfish from coastal locations of Istria. Veterinarska stanica, 46 (1), 9-17.

Botello, A. V., Villanueva, F. S., Rivera, R. F., Velandia, A. L., \& de la Lanza, G. E. (2018). Analysis and tendencies of metals and POPs in a sediment core from the Alvarado Lagoon System (ALS), Veracruz, Mexico. Archives of Environmental Contamination and Toxicology, 75 (1), 157-173.

Broadaway, B. J. (2012). The relation among essential habitat, ocean acidification, and calcification on the Nantucket bay scallop (Argopecten irradians). Dissertation Thesis, Environmental, Earth and Ocean Sciences Program, University of Massachusetts Boston.

Büyükateş, Y. (2017). Demir, sülfür ve silis döngüsü. In R. Witzel (Ed.), Limnoloji Göl ve Nehir Ekosistemleri (pp 289-328). Ankara: Nobel Akademik Yayınclık.

Cai, C. \& Wang, W. X. (2019). Inter-species difference of copper accumulation in three species of marine mussels: Implication fo biomonitoring. Science of the Total Environment, 692, 1029-1036. DOI:10.1016/j.scitotenv.2019.07.298

Cashman, K. D. (2006). A prebiotic substance persistently enhances intestinal calcium absorption and increases bone mineralization in young adolescents. Nutrition Reviews, 64 (4), 189-196. DOI:10.1111/j.17534887.2006.tb00201.x

Chapman, P. M., \& Wang, F. (2001). Assessing sediment contamination in estuaries. Environmental Toxicology and Chemistry: An International Journal, 20 (1), 3-22. DOI:10.1002/etc.5620200102

Cheriyan, E., Sreekanth, A., Mrudulrag, S. K. \& Sujatha, C. H. (2015). Evaluation of metal enrichment and trophic status on the basis of biogeochemical analysis of shelf sediments of the Southeastern Arabian Sea, India. Continental Shelf Research, 108, 1-11. DOI:10.1016/j.csr.2015.08.007

Clark, R. B. (1992). Marine pollution. Oxford: Clarendon Press.
Codex, (2007). Codex Alimentarius Commission: Procedural Manual. Food and Agriculture Organization of the United Nations. http://www.fao.org/3/a1472e/a1472e00.htm (25.04.2021)

Çetingül, V. \& Aysel, V. (1998). Ekonomik değerdeki bazı kahverengi ve kırmızı alglerin ağır metal birikim düzeyleri. Ege Üniversitesi Su Ürünleri Fakültesi Dergisi, 15 (1-2), 63-76.

Culha, S. T., Yabanlı, M., Baki, B. \& Yozukmaz, A. (2016). Heavy metals in tissues of scorpionfish (Scorpaena porcus) caught from Black Sea (Turkey) and potential risks to human health. Environmental Science and Pollution Research, 23, 20882-20892.

DOI:10.1007/s11356-016-7337-2

ÇŞB, (2020). Kıyı ve Deniz Sularındaki Besin Maddeleri. https://cevreselgostergeler.csb.gov.tr/kiyi-ve-deniz-sularindaki-besinmaddeleri-i-91719 (25.04.2021)

Dame, R. F. \& Allen, D. M. (1996). Between estuaries and the sea. Journal of Experimental Marine Biology and Ecology, 200 (1-2), 169-185. DOI:10.1016/S0022-0981(96)02642-1

Din, Z. B. (1992). Use of aluminium to normalize heavy-metal data from estuarine and coastal sediments of Straits of Melaka. Marine Pollution Bulletin, 24 (10), 484-491. https://doi.org/10.1016/0025-326X(92)90472-I

EFSA, (2013). Dietary exposure to aluminium-containing food additives. 10 (4): 411E.

El-Shenawy, N. S., Loutfy, N., Soliman, M. F., Tadros, M. M. \& El-Azeez, A A. A. (2016). Metals bioaccumulation in two edible bivalves and health risk assessment. Environmental Monitoring and Assessment, 188 (3), 139. DOI: $10.1007 /$ s10661-016-5145-2

El-Sikaily, A., Khaled, A., \& El Nemr, A. (2004). Heavy metals monitoring using bivalves from Mediterranean Sea and Red Sea. Environmental Monitoring and Assessment, 98 (1-3), 41-58. DOI:10.1023/B:EMAS.0000038178.98985.5d

EPA (1994). Microwave assisted acid digestion of sediments, sludges, soils, and oils. Method 3051.

FAO (2010). Statistics Division Food Security Statistics, Food Consumption. http://www.fao.org/fishery/statistics/global-consumption/en (21.06.2010)

FAO/WHO, (1993). Evaluation of ceratin food additives and contaminants. Forty-first report of the Joint FAO/WHO Expert Committee on Food Additives, Geneva

FAO/WHO, (2002). Human vitamin and mineral requirements. Report of a joint FAONHO Expert Consultation, Bangkok, Thailand. http://www.fao.org/3/y2809e/y2809e.pdf (25.4.2021)

FAO/WHO, (2004) Summary of evaluations performed by the joint FAO/WHO expert committee on food additives (JECFA 1956-2003). ILSI Press International Life Sciences Institute, Washington

FAO/WHO, (2010). Safety evaluation of certain food additives. Seventy-first meeting of the Joint FAO/WHO Expert Committee on Food Additives, Geneva.

Fitzwater, S. E., Johnson, K. S., Gordon, R. M., Coale, K. H. \& Smith Jr, W O. (2000). Trace metal concentrations in the Ross Sea and their relationship with nutrients and phytoplankton growth. Deep Sea Research Part II: Topical Studies in Oceanography, 47 (15-16), 31593179. DOI:10.1016/S0967-0645(00)00063-1

Fuentes, A., Fernández-Segovia, I., Escriche, I. \& Serra, J. A. (2009). Comparison of physico-chemical parameters and composition of mussels (Mytilus galloprovincialis Lmk.) from different Spanish origins. Food Chemistry, $112 \quad$ (2), 295-302. DOI:10.1016/j.foodchem.2008.05.064

Gabriel, K. R. (1971). The biplot graphic display of matrices with application to principal component analysis. Biometrika, 58 (3), 453-467. DOI:10.1093/biomet/58.3.453

Geldiay, R. \& Kocataş, A. (1988). Beginning to Marine Biology. , İzmir: Ege University, Science Faculty Book Series (In Turkish).

Gower, J. C. \& Hand, D. J. (1996). Biplots. London UK: Chapman\&Hall. 
Gökoglu, N., Yerlikaya, P. \& Gokoglu, M. (2008). Trace elements in edible tissues of three shrimp species (Penaeus semisulcatus, Parapenaeus longirostris and Paleomon serratus). Journal of the Science of Food and Agriculture, 88 (2), 175-178. DOI:10.1002/jsfa.3086

Grasse, P., Ryabenko, E., Ehlert, C., Altabet, M. A. \& Frank, M. (2016). Silicon and nitrogen cycling in the upwelling area off Peru: A dual isotope approach. Limnology and Oceanography, 61(5), 1661-1676. DOI:10.1002/Ino.10324

GTHB (1997). Türkiye Kıyılarındaki Lagünlerin Yönetim ve Geliştirme Stratejileri ve Islah. Tarım ve Köy İşleri Bakanlığı. Tarımsal Üretim ve Geliştirme Genel Müdürlüğü. 2(6), 384-988.

Hambidge, M. (2000). Human zinc deficiency. The Journal of Nutrition, 130 (5), 1344S-1349S. DOI:10.1093/jn/130.5.1344S

Hellström-Westas, L. \& Rosén, I. (2006). Continuous brain-function monitoring: state of the art in clinical practice. In Seminars in Fetal and Neonatal Medicine 11 (6), 503-511. DOI:10.1016/j.siny.2006.07.011

Hogstrand, C. \& Haux, C. (1991). Binding and detoxification of heavy metals in lower vertebrates with reference to metallothionein. Comparative Biochemistry and Physiology Part C: Comparative Pharmacology, 100 (1-2), 137-141. DOI:10.1016/0742-8413(91)90140-0

İnan, Y. \& Gül, M. (2001). Biyokimya. Ankara: Nobel Yayın Dağıtım

Javed, M. \& Usmani, N. (2016). Accumulation of heavy metals and human health risk assessment via the consumption of freshwater fish Mastacembelus armatus inhabiting, thermal power plant effluent loaded canal. SpringerPlus, 5(1), 1-8. DOI:10.1186/s40064-016-2471-3

Karadeniz, T. (2004). Şifalı meyveler (Meyvelerle beslenme ve tedavi şekilleri). İstanbul: Burcan Ofset Matbaacılık Sanayi.

Karl, D. M. R., Letelier, D., Hebel, L., Tapas, J., Dore, J., Christian, C. \& Winn, C. (1995). Ecosystem changes in the North Pacific Subtropical Gyre attributed to the 1991-92 E1 Nino. Nature, 373, 230-234. DOI:10.1038/373230a0

Kükrer, S., Erginal, A. E., Kılıç, Ş., Bay, Özender, Akarsu, T. \& Öztura, E. (2020). Ecological risk assessment of surface sediments of Çardak Lagoon along a human disturbance gradient. Environmental Monitoring and Assessment, 192- 359. DOI:10.1007/s10661-020-08336-9.

Larson, M. (2012). Coastal lagoons. In: L. Bengtsson.et al. (Eds.), Encyclopedia of Lakes and Reservoirs (pp. 171-174).Netherlands: Springer. DOI: 10.1007/978-1-4020-4410-6_236

Lewis, B. L. \& Luther III, G. W. (2000). Processes controlling the distribution and cycling of manganese in the oxygen minimum zone of the Arabian Sea. Deep Sea Research Part II: Topical Studies in Oceanography, 47 (7-8), 1541-1561. DOI:10.1016/S0967-0645(99)00153-8

Lök, A., Çolakoğlu, S., Acarlı, S., Serdar, S., Küçükdermenci, A., Yiğitkurt, S., Kırtık, A. \& Güler, M. (2010). Heavy metal concentration in the mediterranean mussels (Mytilus galloprovincialis) collected from the Dardanelles. In: CIESM $39^{\text {th }}$ Congress (pp. 278) Venezia, Italy.

Maanan, M., Saddik, M., Maanan, M., Chaibi, M., Assobhei, O. \& Zourarah, B. (2015). Environmental and ecological risk assessment of heavy metals in sediments of Nador lagoon, Morocco. Ecological Indicators, 48, 616-626. DOI:10.1016/j.ecolind.2014.09.034

Manthey-Karl, M., Lehmann, I., Ostermeyer, U., Rehbein, H. \& Schröder, U. (2015). Meat composition and quality assessment of king scallops (Pecten maximus) and frozen Atlantic Sea Scallops (Placopecten magellanicus) on a Retail Level. Foods, 4 (4), 524-546. DOI:10.3390/foods4040524

McLusky, D. S., Bryant, Victoria, B. \& Campbell, R. (1986). The effects of temperature and salinity on the toxicity of heavy metals to marine and estuarine invertebrates. Oceanography and Marine Biology Annual Review, 24, 481-520.

Mendez, E., Giudice, H., Pereira, A., Inocente, G. \& Medina, D. (2001). Total mercury content-fish weight relationship in swordfish (Xiphias gladius) caught in the Southwest Atlantic Ocean. Journal of Food Composition and Analysis, 14 (5), 453-460. DOI:10.1006/jfca.2001.1005

Moffett, J. W., Brand, L. E., Croot, P. L. \& Barbeau, K. A. (1997). Cu speciation and cyanobacterial distribution in harbors subject to anthropogenic $\mathrm{Cu}$ inputs. Limnology and Oceanography, 42 (5), 789799. DOI:10.4319//o.1997.42.5.0789
Nurnadia, A. A., Azrina, A., Amin, I, Mohd Yunus, A. S. \& Mohd Izuan Effendi, H. (2013). Mineral contents of selected marine fish and shellfish from the west coast of Peninsular Malaysia. International Food Research Journal, 20 (1), 431-437.

Monteiro, P. M., \& Roychoudhury, A. N. (2005). Spatial characteristics of sediment trace metals in an eastern boundary upwelling retention area (St. Helena Bay, South Africa): a hydrodynamic-biological pump hypothesis. Estuarine, Coastal and Shelf Science, 65, 123-134. DOI:10.1016/j.ecss.2005.05.013

Morel, F. M. M., Reinfelder, J. R., Roberts, S. B., Chamberlain, C. P., Lee, J. G. \& Yee, D. (1994). Zinc and carbon co-limitation of marine phytoplankton. Nature, 369(6483), 740-742. DOI:10.1038/369740a0

O'Connor, T. P. (1996). Trens in chemical concentrations in mussels and oysters collected along de US coast from 1986 to 1993. Marine Environmental Research, 41(2), 183-200. DOI:10.1016/0141-1136(95)00011-9

Orban, E., Di Lena, G., Nevigato, T., Casini, I., Marzetti, A. \& Caproni, R. (2002). Seasonal changes in meat content, condition index and chemical composition of mussels (Mytilus galloprovincialis) cultured in two different Italian sites. Food Chemistry, 77, 57-65. DOI:10.1016/S0308-8146(01)00322-3

Orban, E., Di Lena, G., Nevigato, T., Casini, I., Caproni, R., Santaroni, G. \& Giulini, G. (2007). Nutritional and commercial quality of the striped venus clam, Chamelea gallina, from the Adriatic sea. Food Chemistry, 101 (3), 1063-1070. DOI:10.1016/j.foodchem.2006.03.005

Özden, Ö. \& Erkan, N. (2011). A preliminary study of amino acid and mineral profiles of important and estimable 21 seafood species. British Food Journal, 113 (4), 457-469. DOI:10.1108/00070701111123943

Periyasamy, N., Murugan,, S. \& Bharadhirajan, P. (2014). Biochemical composition of marine bivalve Donax incarnatus (Gmelin, 1791) from Cuddalore Southeast coast of India. International Journal of Advanced in Pharmacy, Biology and Chemistry, 3, 575-582.

Phillips, D. J. H. \& Rainbow, P. S. (1994). Biomonitoring of trace aquatic contaminants, Environmental Management Sweies, London: Chapman \& Hall. DOI:10.1007/978-94-011-2122-4

Plessi, M., Bertelli, D. \& Monzani, A. (2001). Mercury and selenium content in selected seafood. Journal of Food Composition and Analysis, 14 (5), 461-467. DOI:10.1006/jfca.2001.1003

Prato, E., Biandolino, F., Parlapiano, I., Giandomenico, S., Denti, G., Calò, M., Spada, L. \& Di Leo, A. (2019a). Proximate, fatty acids and metals in edible marine bivalves from Italian market: beneficial and risk for consumers health. Science of The Total Environment, 648, 153-163. DOI:10.1016/j.scitotenv.2018.07.382

Prato E., Biandolino, F., Parlapiano, I., Papa, L., Denti, G. \& Fanelli, G. (2019b). Seasonal changes of commercial traits, proximate and fatty acid compositions of the scallop Flexopecten glaber from the Mediterranean Sea (Southern Italy). PeerJ, 7, 5810. DOI: $10.7717 /$ peerj.5810

Rayman, M. P. (2020). Selenium intake, status, and health: A complex relationship. Hormones, 19, 9-14. DOI:10.1007/s42000-019-00125-5

Schümann, K., Ettle, T., Szegner, B., Elsenhans, B. \& Solomons, N. W. (2007). On risks and benefits of iron supplementation recommendations for iron intake revisited. Journal of Trace Elements in Medicine and Biology, 21 (3), 147-168. DOI:10.1016/j.jtemb.2007.06.002

Selinus, O., Lindh, U., Fuge, R., Centeno, J., Alloway, B., Smedley, P. \& Finkelman, R. (2005). Essentials of Medical Geology. Impacts of the Natural Environment on Public Health. China: Elsevier Academic Press.

Sevgi, S. \& Ulutarhan- Süzer, E. (2019). Assessment of $\mathrm{Hg}, \mathrm{Cd}, \mathrm{Pb}$ and $\mathrm{Cr}$ accumulations in razor clam (Solen marginatus) from the Homa Lagoon. Ege Journal of Fisheries and Aquatic Sciences, 36 (1), 31-39. DOI:10.12714/egejfas.2019.36.1.04

Shaked, Y., Xu, Y., Leblanc, K., \& Morel, F. M. (2006). Zinc availability and alkaline phosphatase activity in Emiliania huxleyi: Implications for $\mathrm{Zn}-\mathrm{P}$ co-limitation in the ocean. Limnology and Oceanography, 51 (1), 299309. DOI:10.4319/lo.2006.51.1.0299 
Shariati, M. \& Yahyaabadi, S. (2006). The effects of different concentrations of cadmium on the growth rate and beta-carotene synthesis in unicellular green algae Dunaliella salina. Iranian Journal of Science and Technology Transaction a-Science, 30 (A1), 57-63.

Sharp, J. D. \& Byrne, R. H. (2020). Interpreting measurements of total alkalinity in marine and estuarine waters in the presence of protonbinding organic matter. Deep Sea Research Part I: Oceanographic Research Papers, 165, 103338. DOI:10.1016/j.dsr.2020.103338

Sidwell, V. D., Buzzell, D. H., Foncannon, P. R. \& Smith, A. L. (1977) Composition of the edible portion of raw (fresh or frozen) crustaceans, finfish, and mollusks. II. macroelements: sodium, potassium, chlorine, calcium, phosphorus, and magnesium. Marine Fisheries Review, 39 (1), 1-11.

Skinner, C., Turoczy, N. J., Jones, P. L., Barnett, D., \& Hodges, R. (2004). Heavy metal concentrations in wild and cultured Blacklip Abalone (Haliotis rubra Leach) from southern Australian waters. Food Chemistry, 85 (3), 351-356. DOI: 10.1016/j.foodchem.2003.07.011

Steinbrenner, H., Speckmann, B. \& Klotz, L. O. (2016). Selenoproteins: Antioxidant selenoenzymes and beyond. Archieves of Biochemistry and Biophysics, 595, 113-119. DOI:10.1016/j.abb.2015.06.024

Stoltzfus R. J. \& Dreyfuss M. L. (1998). Guidelines for the use of Iron supplements to prevent and treat iron deficiency anemia. Washington: Ilsi Press.

Storelli, M. M., Storelli, A. \& Marcotrigiano, G. O. (2000). Heavy metals in mussels (Mytilus galloprovincialis) from the Ionian Sea, Italy. Journal of Food Protection, 63 (2), 273-276. DOI:10.4315/0362-028X-63.2.273

Tapiero, H., Townsend, D. Á. \& Tew, K. D. (2003). Trace elements in human physiology and pathology. Copper. Biomedicine \& pharmacotherapy, 57(9), 386-398. DOI:10.1016/S0753-3322(03)00012-X

Tarley, C. R., Coltro, W. K., Matsushita, M. \& de Souza, N. E. (2001). Characteristic levels of some heavy metals from Brazilian canned sardines (Sardinella brasiliensis). Journal of Food Composition and Analysis, 14 (6), 611-617. DOI:10.1006/jfca.2001.1028

Tokatı, C. \& Ustaoğlu, F. (2021). Meriç delta balıklarında toksik metal birikimlerinin değerlendirilmesi: Muhtemel insan sağlığı riskleri. Acta Aquatica Turcica, 17(1), 136-145. DOI:10.22392/actaquatr.769656

Ulutarhan, E., Darılmaz, E., Kontas, A., Bilgin, M., Alyuruk, H., Altay, O. \& Sevgi, S. (2019). Seasonal variations of multi-biomarker responses to metals and pesticides pollution in M. galloprovincialis and $T$. decussatus from Homa Lagoon, Eastern Aegean Sea. Marine Pollution Bulletin, 141, 176-186. DOI:10.1016/j.marpolbul.2019.02.035

USEPA (U.S. Environmental Protection Agency) (1989) Risk assessment guidance for superfund. Volume I: human health evaluation manual
(Part A). Interim Final Office of Emergency and Remedial Response EPA/540/1-89/002

USEPA (U.S. Environmental Protection Agency) (2011) Exposure factors handbook 2011 edition (Final). National Center for Environmental Assessment, Office of Research and Development, Washington D.C

USEPA (U.S. Environmental Protection Agency) (2019a). Regional screening levels (RSLs) - equations. https://www.epa.gov/risk/regional-screeninglevels-rsls-equations

USEPA (U.S. Environmental Protection Agency) (2019b) Regional screening level (RSL) summary table (TR=1E-06 $\mathrm{THQ}=1.0)$. https://semspub.epa.gov/work/HQ/197414.pdf

Ustaoğlu, M. R., Özdemir Mis, D. \& Aygen, C. (2012). Observations on zooplankton in some lagoons in Turkey. J. Black Sea/Mediterranean Environment, 18 (2), 208-222.

Ünsal, M. (2004). 2003-2004 Yıllarında düzenlenen tarımsal çevre ve su kirliliği hizmetiçi eğitim semineri notları, Tarım ve Köyişleri Bakanlığı Koruma ve Kontrol Genel Müdürlüğü (pp. 159). Ankara.

Vural, P. \& Acarlı, S. (2018). Assessment of Çardak Lagoon for fisheries and aquaculture production. In: S. Canbulat, N. Gültepe, A. Türkyılmaz (Eds.), International Symposium Ecology 2018 (pp. 1051). Kastamonu, Turkey: Abstract Book.

Yakıncı, Z. D. \& Kök, M. (2016). Borun sağlık alanında kullanımı. Inönü Üniversitesi Sağlık Hizmetleri Meslek Yüksekokulu Dergisi, 5 (7), 36-44.

Yaşar, H. \& Melek, S. (2003). Besinler ve beslenme. İstanbul: Nobel Yayın Dağıtım

Yiğitbaşıoğlu, H. (2004). Türkiye için önemli bir maden: Bor (An Important Ore for Turkey: Boron). Coğrafi Bilimler Dergisi/Turkish Journal of Geographical Sciences, 2(2), 13-25. DOI: 10.1501/Cogbil_0000000046

Walker, J. M., Tsivkovskii, R. \& Lutsenko, S. (2002). Metallochaperone Atox1 transfers copper to the NH2-terminal domain of the Wilson's disease protein and regulates its catalytic activity. Journal of Biological Chemistry, 277 (31), 27953-27959. DOI:10.1074/jbc.M203845200

Warnau, M., Teyssié, J. L. \& Fowler, S. W. (1996). Biokinetics of selected heavy metals and radionuclides in the common Mediterranean Echinoid Paracentrotus lividus: Sea water and food exposures. Marine Ecology Progress Series, 141, 83-94. DOI: 10.3354/meps141083

Wen J. \& Hu C. (2010). Elemental composition of commercial sea cucumbers (Holothurians). Food Additives and Contaminants, 3 (4), 246-252. DOI:10.1080/19393210.2010.520340

WHO (1996). Trace elements in human nutrition and health. Geneva

WHO (2006). Guidelines on food fortification with micronutrients. World Health Organization

WHO (2012). Guideline: sodium intake for adults and children. WorldHealth Organization, Geneva.

Yaman M., Karaaslan N.M. \& Yaman I.H. (2014) Seasonal variations in toxic metal levels of two fish species, Mugil cephalus and Mullus barbatus and estimation of risk for children. Bulletin of Environmental Contamination and Toxicology, 93,344-349. DOI:10.1007/s00128-014-1342-2 